\title{
SPATIAL ANALYSIS AND GEOMORPHIC CHARACTERISTICS OF CORAL REEFS ON THE EASTERN PART OF LOMBOK, INDONESIA
}

\author{
Bachtiar MUTAQIN ${ }^{1,2}$ (D)
}

DOI: 10.21163/GT_2020.152.19

\begin{abstract}
:
The eastern part of Lombok Island is a highly dynamic environment with many physical processes as well as very complex landuse. In addition to the anthropogenic origin, sedimentation in this area also occurs due to natural origins, such as volcanic processes. Due to hydrological processes since the 1257 CE eruption of Samalas volcano, almost half of the materials were transported and deposited to the coastal area. These deposits can affect the state of the aquatic environment, so they, directly and indirectly, affect the coral reef conditions. However, the spatial information of coral reefs in this area is rarely known. Therefore, the spatial distributions of coral reefs in this area should be investigated to distinguish and determine the factors that regulate its patterns. The multidisciplinary approach, including geomorphological survey, remote sensing and geographic information system (GIS), as well as geostatistical analysis, has been used to gain a deep understanding of the spatial distribution and geomorphic features of coral reefs in the eastern part of Lombok. Our results show that coral reefs on the eastern part of Lombok are mostly fringing reefs and developed on shallow continental shelves in depth between 0-20 m and located close to the main island. In addition, coast typology in the eastern part of Lombok divided into river deposition coast and wave erosion coast. Finally, the absence of coral reefs in some areas in the eastern part of Lombok can be caused by sedimentation and pollution from the river as well as the extraction of remnant coral reefs.
\end{abstract}

Key-words: Sedimentation; Coastal; Coral reef; DEM; Samalas; Lombok.

\section{INTRODUCTION}

The existence of primary ecosystems in the coastal area, i.e., coral reefs, mangroves, and seagrass (Guannel et al. 2016; Mutaqin et al., 2020; Marfai et al., 2020) may affect the coastal landscape dynamics. Coral reef as the first barrier can reduce the energy of waves that strike the shore (Ferrario et al., 2014; Costa et al., 2016; Hongo et al., 2018; Harris et al., 2018). Coral reef as coastal protection may also minimize coastal erosion (Silva et al., 2016; Reguero et al., 2018) and significantly reduce the risk from coastal hazards for about 200 million people in the world (Ferrario et al., 2014). Coral typically live in tropical and subtropical areas with favorable oceanographic conditions, such as water temperatures between $18-29^{\circ} \mathrm{C}$, salinity between $32-42 \%$, as well as clear water where the intense sunlight still can penetrate it (Davidson-Arnot, 2010). Disturbances in those advantageous conditions and environment undoubtedly can affect the existence of coral's life.

One of these disturbances is from volcanic origins. Volcanic materials may reach the sea following to the eruption, either directly and indirectly through the river, and it can result in disturbances in the ocean environment (Maniwavie et al., 2001; Vroom and Zgliczynski, 2011; Mutaqin et al., 2019a; Mutaqin et al., 2019b; Mutaqin and Lavigne, 2019). Disturbances in the ocean due to volcanic ash, pumice rafts, as well as Pyroclastic Density Current (PDC) deposits, may affect the coral reefs, e.g., coral bleaching which triggers mortality of corals (Maniwavie et al., 2001; Schils, 2012). In addition to the mortality of corals, there are other negative impacts of lahars, lava flows, and volcanic ash that deposited on coral reefs: 1) sunlight penetration has decreased that affect the

\footnotetext{
${ }^{1}$ Universitas Gadjah Mada, Faculty of Geography, Coastal and Watershed Research Group, 55281

Yogyakarta, Indonesia, mutaqin@ugm.ac.id.

${ }^{2}$ Université Paris 1 Panthéon Sorbonne, Laboratoire de Géographie Physique UMR 8591, 92190 Paris,

France, mutaqin@ugm.ac.id
} 
coral's photosynthesis, changes in the chemical elements in the ocean (Reuter and Piller, 2011), and 2) nutrient enrichments triggering transformations in the benthic structure (Tomascik et al., 1996; Vroom and Zgliczynski, 2011; Schils, 2012).

As the most powerful case in the recent eruptive history of Lombok (Lavigne et al., 2013; Vidal et al., 2015; Mutaqin et al., 2019a), volcanic materials that were expelled by the Samalas volcano in $1257 \mathrm{CE}$ covered the entire of Lombok Island, and until now it still remains and exploited by the local people through the extraction (Fig. 1). The exploitation of materials from the Samalas eruption in Lombok started intensively since the early 1980s. The pumices (Fig. 1a) are exported mainly to Asia (China 59.4\%, South Korea 20.1\%, Vietnam 8.7\%, and Thailand 3.2\%) as a building material in the manufacture of concrete and as an abrasive material (Statistics Indonesia, 2017). The extraction, which is widespread all over Lombok Island (Fig. 1b), has accelerated the natural landscape evolution. As a result, their exploitation allows the extension of cultivated areas from under-exploited land to large rice fields (Fig. 1c) as well as causes the sediment in the rivers, which then flows into the sea and leads to sedimentation.

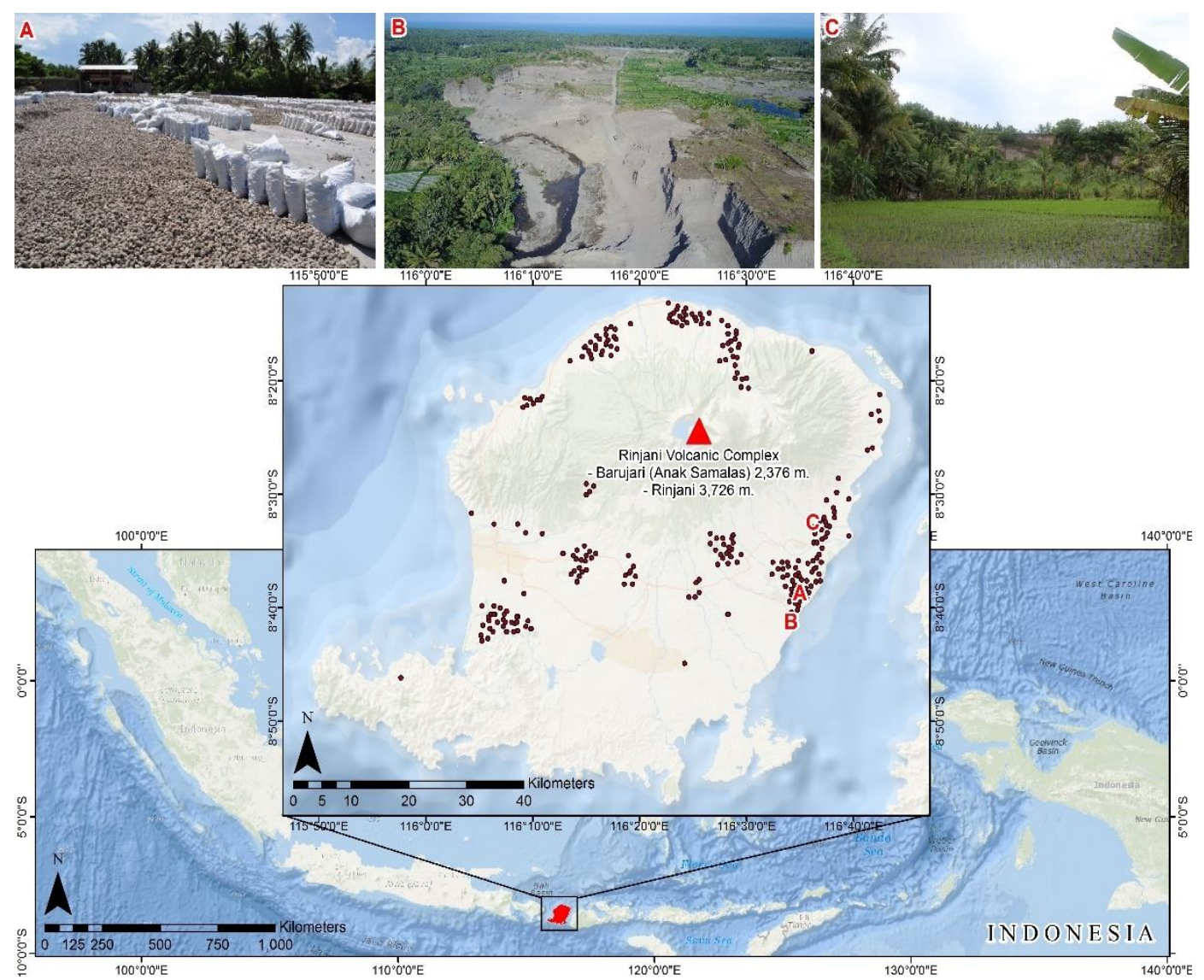

Fig. 1. Location of volcanic materials extraction in Lombok Island: a) pumice from the extraction, b) pumice quarry, and c) rice-fields area as a "benefit" from the exploitation.

Based on Fig. 1, we can identify that the pumices extractions are mostly found in the eastern part of Lombok and may disturb the ocean conditions. However, the spatial configuration of coral reefs in this area is largely unexplored. Coral reefs monitoring and research mostly located in the western part of Lombok and limited to their ecosystem services (Pradjoko et al., 2015; Kurniawan et al., 2016; Chen et al., 2019). The novelty of this research is related to the spatial distributions of coral reefs in 
the eastern part of Lombok in relation to landscape dynamics, especially from volcanic origins, which should be investigated to distinguish and determine the factors that regulate its patterns.

This research aims at the investigation of spatial distributions of coral reefs in the eastern part of Lombok as well as its correlation with the volcanic activities on Lombok Island. In the present study, we, therefore, also compared the spatial distribution of coral reefs and bathymetric information as well as coast typologies on the eastern part of Lombok.

\section{METHODS}

The multidisciplinary approach between geomorphological surveys, remote sensing and geographic information system (GIS) techniques, as well as geostatistical analysis, were used to acquire comprehensive information on the subject of spatial distribution and geomorphic characteristics of coral reefs on the eastern part of Lombok Island. There are five data as an input to further analyze, both in the field and in the laboratory, i.e., coral reefs database; the 1998 Indonesian topographic map with a scale of 1:25,000; the 2014 Indonesian bathymetric map with a scale of 1:200,000; satellite imagery of SPOT 6 and 7; and Indonesian Digital Elevation Model with a spatial resolution of 0.27-arcsecond (Fig. 2). This study collected three kinds of data: (1) spatial distribution of coral reefs, (2) digital elevation model (DEM), and (3) coast typology.

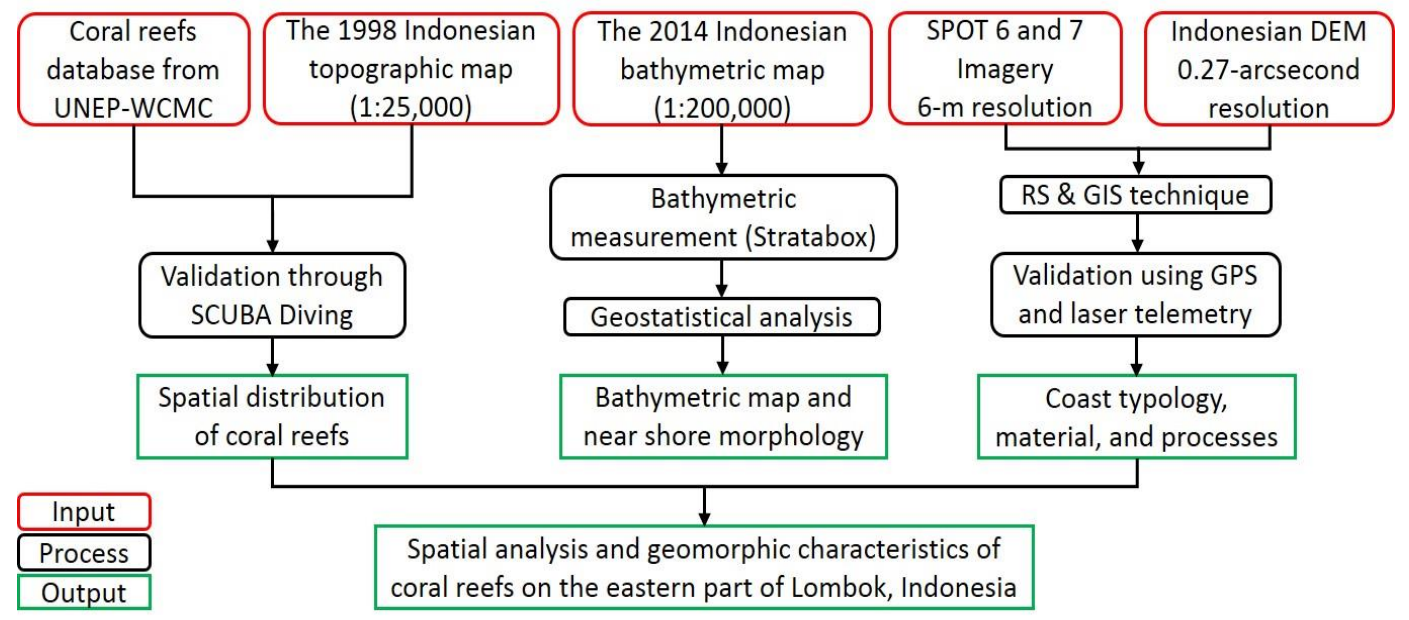

Fig. 2. Research methodology on the spatial analysis and geomorphic characteristics of coral reefs.

We used the most comprehensive distribution data of coral reefs from the UNEP World Conservation Monitoring Centre (UNEP-WCMC) and the WorldFish Centre (UNEP-WCMC et al., 2018), combined with data from the Indonesian Geospatial Information Agency (BIG) as a baseline map for a detailed survey conducted in 2016 and 2017 (Fig. 3a). The use of GIS technologies will help to perform spatial analysis here. The next step is to develop a DEM from the 2014 bathymetric map of Indonesia at a scale of 1:200,000, produced by the Indonesian Hydro-Oceanographic Agency, which detailed with field measurements using a high-resolution marine geophysical instrument, called StrataBox (Fig. 3b).

DEM data is essential while studying the Earth's morphology (Nistor et al., 2019; Kongmuang et al., 2020). DEM data generated using geostatistical analysis, i.e., the simple Kriging process with the first order for trend removal and an exponential semivariogram model. Kriging was used in this study since the data is normally distributed and stationary. Furthermore, Kriging is the most excellent interpolation method since it is unbiased, it performs better, and had the smallest error values (Zimmerman et al., 1999; Schwendel et al., 2012; Arun, 2013; Arétouyap et al., 2016; Mutaqin et al., 2019a). 
Classification of coast typology refers to the most dominant processes in the coast from Shepard (1973), i.e., the primary coast, which is mainly formed and controlled by land processes, and the secondary coast, which is shaped primarily by the sea or by marine organisms.

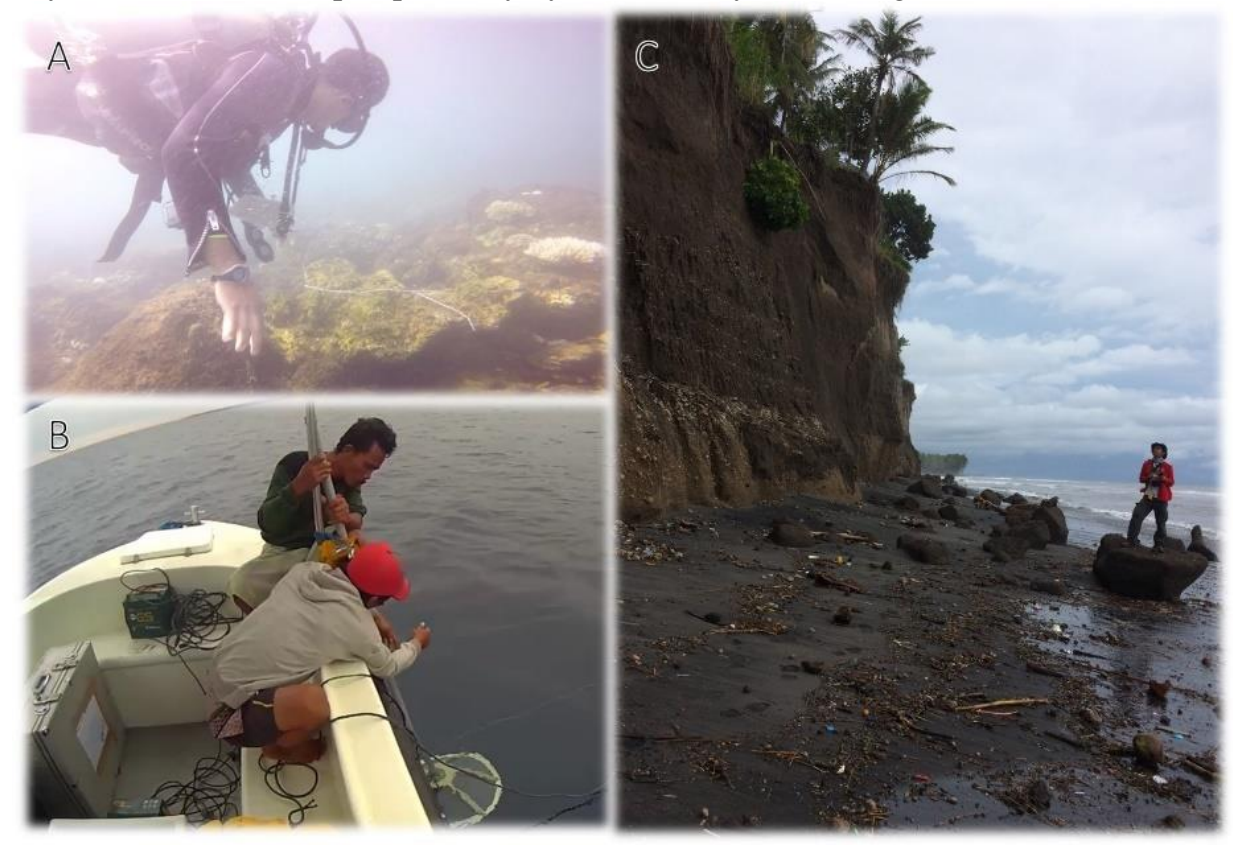

Fig. 3. Survey and field measurements of: a) coral reefs, b) bathymetric data, and c) coast typology.

Coast typology identified from a 2016 of SPOT 6 and 7 imagery satellite provided by the National Institute of Aeronautics and Space of Indonesia, which combined with Indonesian DEM data with a spatial resolution of 0.27 -arcsecond provided by BIG (http://tides.big.go.id/DEMNAS/), as well as field measurements in 2017 and 2019 (Fig. 3c).

\section{RESULTS AND DISCUSSIONS}

\subsection{Computational analysis}

The value of the mean, RMSE, mean standardized error, root mean squared standardized error, and average standard error is shown in Table 1 which calculates automatically in ArcGIS software based on Equations (1)-(5):

Mean:

RMSE value:

Mean standardized error:

Root mean squared standardized error:

$$
\begin{gathered}
\sum_{i=1}^{n}\left(\hat{Z}\left(s_{i}\right)-z\left(s_{i}\right)\right) / n \\
\sqrt{\sum_{i=1}^{n}\left(\hat{Z}\left(s_{i}\right)-z\left(s_{i}\right)\right)^{2} / n} \\
\sum_{i=1}^{n}\left(\hat{Z}\left(s_{i}\right)-z\left(s_{i}\right)\right) / \hat{\sigma}\left(s_{i}\right)
\end{gathered}
$$


Average standard error:

$$
\sqrt{\frac{\sum_{i=1}^{n} \hat{\sigma}^{2}\left(s_{i}\right)}{n}}
$$

where $\mathrm{Z}\left(\mathrm{s}_{\mathrm{i}}\right)$ is the measured value at the $i$ th location; $\mathrm{n}$ is the number of measured values; and $\sigma$ is variance parameter.

Table 1.

Cross-validation for the bathymetric model.

\begin{tabular}{|l|r|}
\hline \multicolumn{1}{|c|}{ Parameters } & Value \\
\hline Mean & 0.16 \\
\hline RMSE value & 3.85 \\
\hline Mean standardized error & 0.04 \\
\hline Root mean squared standardized error & 1.66 \\
\hline Average standard error & 2.26 \\
\hline
\end{tabular}

The quality of DEM can be identified through a small RMSE value. The smallest RMSE implies that the algorithm has accurately estimated the calculated values. Furthermore, the validity of DEM data generated using geostatistical analysis can be identified through several criteria, among others: 1) the mean standardized error is near zero; 2) the value of average standard error and the root mean squared prediction error is not far adrift; 3) the value of root mean squared standardized error is approximately 1 (Li and Tang, 2011; Zhu, 2016; Mutaqin et al., 2019a). Based on those parameters, bathymetric models in our study can be categorized as a valid model. The bathymetric model of the Alas Strait, which has $10-\mathrm{m}$ spatial resolution, shows depths varying from $0 \mathrm{~m}$ in the shoreline to a maximum depth of approximately $200 \mathrm{~m}$ in the mid-channel.

\subsection{Spatial distribution of coral reefs}

Based on the bathymetric model and field measurements, we can identify that spatially, coral reefs coverage on the eastern part of Lombok is the most extensive in Lombok Island with an area of $61.89 \mathrm{~km}^{2}$ from total coverage of $137.34 \mathrm{~km}^{2}(45.1 \%)$. Furthermore, coral reefs on the eastern part of Lombok are mostly fringing reefs and developed on shallow continental shelves in depth between 0$20 \mathrm{~m}$ and located close to the main island. Fringing reefs are frequently found on mainland coasts, morphologically simple, and appear as shore-attached organisms (Kennedy and Woodroffe, 2002; Davidson-Arnott, 2010). In the eastern part of Lombok, coral reefs develop mostly in areas with linear sandy beaches as well as in bay heads. However, coral reefs did not found in all areas in the eastern part of Lombok. Four bathymetric profiles were created to obtain detailed information about the spatial distribution of coral reefs which also compare with bathymetric data and coast typology. Profiles A and D were used to represent areas with coral reefs, while profiles B and C represent areas without coral reefs. In bathymetric profile A (Fig. 4a), coral reefs were located in a relatively flat nearshore morphology (slope up to 0.6 degrees), sandy seabed materials, with a distance up to $1 \mathrm{~km}$ seaward, and the depth reach $19 \mathrm{~m}$. Bathymetric profile D (Fig. 4d) shows that coral reefs were located on a very gentle slope (up to 1.1 degrees), sandy seabed materials, up to 13 meters of depth, and a distance of up to $1 \mathrm{~km}$ from the shoreline. In front of the affected area from the $1257 \mathrm{CE}$ Samalas eruption (Mutaqin et al., 2019a), we identified that there were no living coral reefs, represents by profiles B and C (Fig. 4b and Fig. 4c). In a distance of $1 \mathrm{~km}$ toward the sea, profiles B and C have similar morphological characteristics with profiles A and D, i.e., very gentle slope. Still, the depth is only up to $10 \mathrm{~m}$ with the conditions of murky water.

This phenomenon may be triggered by the landscape evolution following the 1257 CE Samalas eruption that produces more than $4.4 \times 10^{6} \mathrm{~m}^{3}$ of pumice-rich PDCs. Following the $1257 \mathrm{CE}$ eruption, volcanic materials from Samalas reached the Alas Strait and resulted in the coast progradation at specific locations along the shoreline, e.g., in Korleko. The $1257 \mathrm{CE}$ materials had buried almost all the pre-eruption coral reefs in this area and highly eroded since then (Mutaqin et al., 2019a). Several studies have also mentioned the impacts of volcanic materials at sea from different perspectives. In 1988, the lava from the eruption of Gunung Api in Banda Island, Indonesia, entered the sea and buried about 70,000 $\mathrm{m}^{2}$ (Casadevall et al., 1989) of the coral reef (Sutarna, 1990) to a depth more than $50 \mathrm{~m}$. 
In other cases, suspended volcanic ash following the $2003 \mathrm{CE}$ eruption in Anatahan, the Northern Mariana Islands reduced the underwater visibility up to 2-meter (Vroom and Zgliczynski, 2011). Consequently, the maximal living coral cover has decreased by about $35 \%$ with poor conditions, and most of them displayed signs of stress in the form of coral bleaching (Vroom and Zgliczynski, 2011).
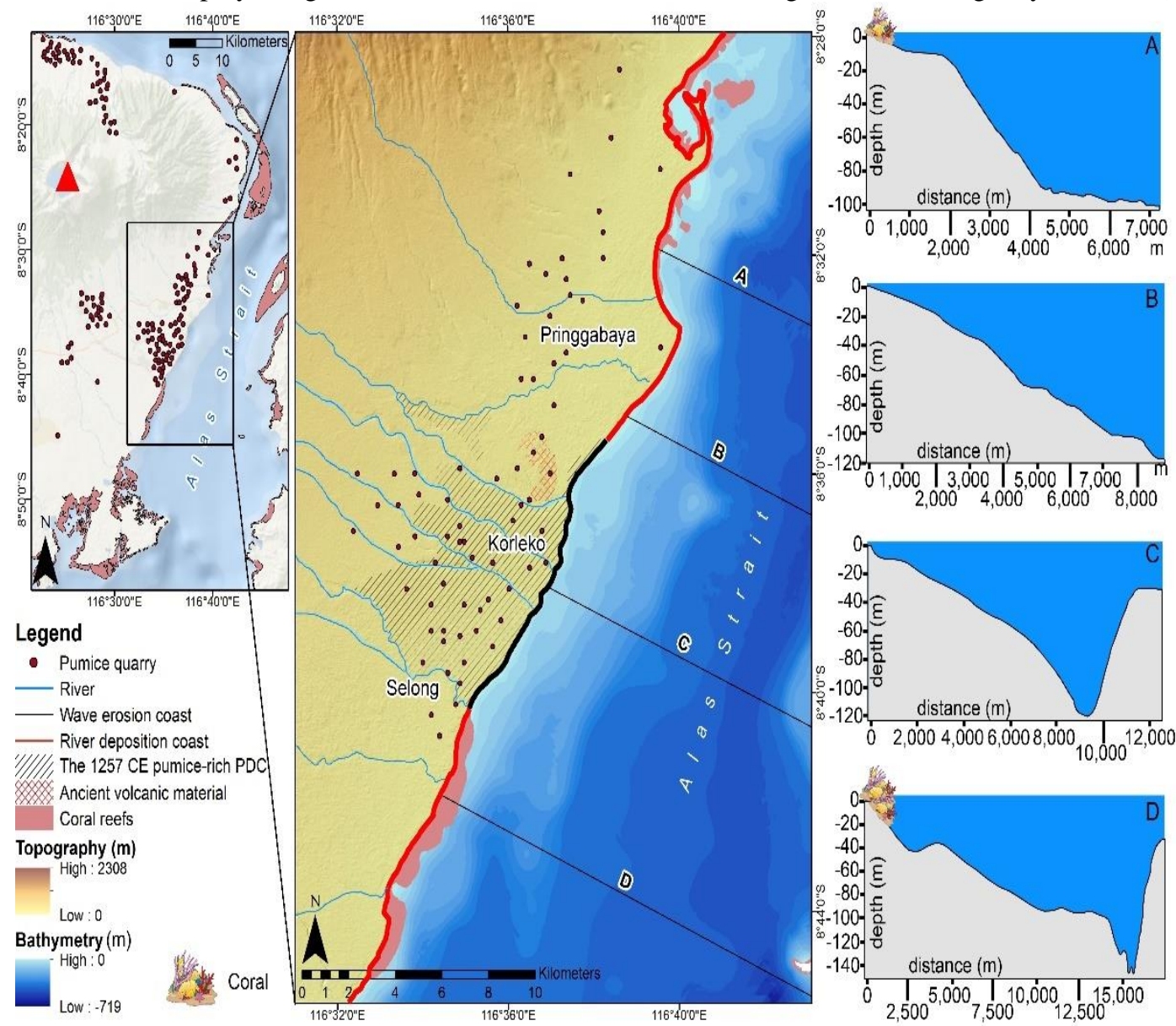

Fig. 4. Spatial distribution of coral reefs and coast typology in the eastern part of Lombok.

In 1994, a volcanic eruption in Rabaul Caldera, Papua New Guinea, produced large volumes of ash and pumice, which completely buried the coral reefs around Rabaul Harbor (Maniwavie et al., 2001). Although the coral reefs had extensively recolonized in the two years following the eruption, the volcanic ash had succeeded in decreasing the live coral cover from $50 \%$ before the eruption to $0 \%$ in the aftermath of the eruption. This rapid recolonization may have happened if the remobilization of volcanic materials from the mainland (i.e., suspended solid sediments and lahars) that reach the sea through the rivers did not disturb the underwater conditions.

Profiles graph of A, B, C, and D show the same patterns of gradient changes in the waters of eastern Lombok. In general, the seabed material of the Alas Strait consists mostly of rock and sand. Nevertheless, there were different materials and dominant processes in the coast of Selong, Korleko, and Pringgabaya. In Korleko, the materials are mostly from the Samalas volcano (pumice-rich PDC and flood derived sand deposits), while in Pringgabaya and Selong are undifferentiated volcanic rocks (e.g., lava, breccia, and tuff) and an ancient debris avalanche, respectively. Coast typology in Korleko also categorized as a wave erosion coast since a straightened, and irregular high cliff only can be found in Korleko. 


\subsection{Coastal dynamics and its geomorphic impacts on coral reefs}

Coastal sedimentation occurs when the eroded material has deposited downstream by runoff into surface waters such as estuaries. In past years, sediment input has dramatically increased in coastal areas due to material from the volcanic eruption (Vogel and Märker, 2010; Ramalho et al., 2013; Mutaqin et al., 2019a). From the end of the $13^{\text {th }}$ to the beginning of the $20^{\text {th }}$ century, coastal evolution in the eastern part of Lombok is dominated by fluvial origin rather than by marine and anthropic origin. After being relatively stable since the $13^{\text {th }}$ century, the coastline on the eastern part of Lombok has receded several hundred meters since the 1980 s, probably due to a combination of natural factors (sea level rise driven by climate change; earthquakes) and human factors.

Since coral reefs are very vulnerable ecosystems, pumice quarry on the eastern part of Lombok, as well as the destruction of the remnant coral reefs for building materials and lime production (Fig. 5a), could have geomorphic impacts and worsen the existence of coral reefs in this area. Eroded volcanic material, either due to natural processes or from quarries, transported by rivers and deposited on estuaries (Fig. 5b). Deposited material from the river, which consists of sand deposits and pumices, accumulated in the nearshore zone and causing murky waters. Furthermore, those materials, along with eroded material from volcanic deposits along the coast, are then transported southward by longshore currents in the Alas Strait. Field measurement shows that within 24 hours, seawater current velocity is more than $1.7 \mathrm{~m} / \mathrm{s}$ that occurs for 9 hours, at the interval between the first and second low water tides and flowing towards the south.


Fig. 4. a) Coral reefs conditions following dynamite fishing, anchor dragging, and coral extraction (Courtesy: A. Landa, 2016); b) sedimentation in the estuary with a background of a cliff (pumice-rich PDC) in Korleko.

Moreover, the activity of dynamite and cyanide fishing also still exists and practiced by some people in Lombok Island, including in the eastern part of Lombok. Since the Holocene era, human activities are mentioned as one of the factors that can affect coastal dynamics (Alizadeh et al., 2015). Thenceforth, human pressures in the coastal area in the form of coral reef extraction had increased due to their needs related to economic factors (Aretano et al., 2017; Mutaqin, 2017), including in the eastern part of Lombok although there is already regulation about it. 


\section{CONCLUSIONS}

The bathymetric model on the eastern part of Lombok was reconstructed using the kriging technique. The model is valid and has the RMSE with the smallest value; hence, in other words, the model is reasonably accurate. In general, coast typology in the eastern part of Lombok consists of two types, i.e., river deposition coast as well as wave erosion coast, like in Korleko. The results show a correlation between the $1257 \mathrm{CE}$ eruption of Samalas with the existence of coral reefs in the eastern part of Lombok. Currently, there is no living coral reef in the nearshore of Korleko. This condition can be caused due to several factors, among others: 1) sedimentation from the river, 2) regular input of acid pumice material in the sea which transported in suspension by the rivers; and 3) illegal activities of coral reefs extraction and destruction of coral reefs for lime production and building materials. These types of studies are important to carry out, not only in Lombok Island but also in another area in Indonesia to understand more detail the impact of volcanic, fluvial, and anthropogenic activities on the coastal ecosystems and its dynamics. Furthermore, the results in this article might be used by the local government and related institutions as a basis for policy-making, especially on the management of coral reefs, sand mining regulation, and marine protected area.

\section{ACKNOWLEDGMENTS}

This article was written as part of a joint research between Universitas Gadjah Mada and Universitas Paris 1 Panthéon Sorbonne. Fieldwork was partially supported by the Centre National de la Recherche Scientifique (CNRS-PICS n²60868). The author also wishes to thank Wisudarahman As Sidiqi (Mitra Geotama), Adrien Landa (Ocean Stream), and Hilman Ahyadi (Universitas Mataram) for participating in the fieldwork. The author dedicates this article to Prof. Sunarto, Prof. Hartono, as well as Dionisius Prasetyo, who passed away recently. Finally, the author would also like to thank the reviewers for their helpful comments on this paper.

\section{R E F E R E N C E S}

Alizadeh, K., Cohen, M., and Behling, H. (2015). Origin and dynamics of the northern South American coastal savanna belt during the Holocene - the role of climate, sea-level, fire, and humans. Quaternary Science Reviews. 122, 51-62. https://doi.org/10.1016/j.quascirev.2015.05.009.

Aretano, R., Parlagreco, L., Semeraro, T., Zurlini, G., Petrosillo, I. (2017). Coastal dynamics vs beach users attitudes and perceptions to enhance environmental conservation and management effectiveness. Marine Pollution Bulletin. 123, 142-155. https://doi.org/10.1016/j.marpolbul.2017.09.003.

Arétouyap, Z., Njandjock Nouck, P., Nouayou, R., Kemgang, F.E.G.K., Toko A.D.P., and Asfahani, J. (2016). Lessening the adverse effect of the semivariogram model selection on an interpolative survey using kriging technique. SpringerPlus 5, 549. https://doi.org/10.1186/s40064-016-2142-4.

Arun, P. (2013). A comparative analysis of different DEM interpolation methods. The Egyptian Journal of Remote Sensing and Space Sciences (16), 133-139. https://doi.org/10.1016/j.ejrs.2013.09.001.

Casadevall, T., Pardyanto, L., Abas, H., and Tulus. (1989). The 1988 eruption of Banda Api volcano, Maluku, Indonesia. Geologi Indonesia. 12, 1, 603-635.

Chen, F., Wu, J., Liu, J., Hu, Y., Chen, X., Lim, P-E., Abdullah, W.M.A., Sjafrie, N.D.M., Adirianto, B. (2019). Comparison of social-value cognition based on different groups: The case of Pulau Payar in Malaysia and Gili Matra in Indonesia. Ocean \& Coastal Management. 173, 1-9. https://doi.org/10.1016/j.ocecoaman.2019.02.010.

Costa, M.B.S.F., Araújo, M., Araújo, T.C.M., Siegle, E. (2016). Influence of reef geometry on wave attenuation

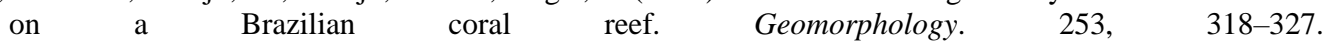
https://doi.org/10.1016/j.geomorph.2015.11.001.

Davidson-Arnott, R. (2010). An Introduction to Coastal Processes and Geomorphology. Cambridge University Press, New York. 458p. 
Ferrario, F., Beck, M.W., Storlazzi, C.D., Micheli, F., Shepard, C.C., and Airoldi, L. (2014). The effectiveness of coral reefs for coastal hazard risk reduction and adaptation. Nature Communications. 5:3794. https://doi.org/10.1038/ncomms4794.

Guannel, G., Arkema, K., Ruggiero, P., Verutes, G. (2016). The Power of Three: Coral Reefs, Seagrasses, and Mangroves Protect Coastal Regions and Increase Their Resilience. PLoS ONE 11(7): e0158094. https://doi.org/10.1371/journal.pone.0158094.

Harris, D.L., Rovere, A., Casella, E., Power, H., Canavesio, R., Collin, A., Pomeroy, A., Webster, J.M., Parravicini, V. (2018). Coral reef structural complexity provides important coastal protection from waves under rising sea levels. Science Advances. 4, 2, eaao4350. https://doi.org/10.1126/sciadv.aao4350.

Hongo, C., Kurihara, H., and Golbuu, Y. (2018). Coral boulders on Melekeok reef in the Palau Islands: An indicator of wave activity associated with tropical cyclones. Marine Geology. 399, 14-22. https://doi.org/10.1016/j.margeo.2018.02.004.

Kennedy, D.M., and Woodroffe, C.D. (2002). Fringing reef growth and morphology: a review. Earth-Science Reviews, 57, (3-4), 255-277. https://doi.org/10.1016/S0012-8252(01)00077-0.

Kongmuang, C., Tantanee, S., Seejata, K. (2020). Urban Flood Hazard Map Using GIS of Muang Sukhothai District, Thailand. Geographia Technica, 15(1), 143-152. http://doi.org/10.21163/GT_2020.151.13.

Kurniawan, F., Adrianto, L., Bengen, D.G., Prasetyo, L.B. (2016). Vulnerability assessment of small islands to tourism: The case of the Marine Tourism Park of the Gili Matra Islands, Indonesia. Global Ecology and Conservation. 6, 308-326. https://doi.org/10.1016/j.gecco.2016.04.001.

Lavigne, F., Degeai, J.-P., Komorowski, J.-C., Guillet, S., Robert, V., Lahitte, P., Oppenheimer, C., Stoffel, M., Vidal, C.M., Surono, Pratomo, I., Wassmer, P., Hajdas, I., Hadmoko, D.S., de Belizal, E. (2013). Source of the great A.D. 1257 mystery eruption unveiled, Samalas volcano, Rinjani Volcanic Complex, Indonesia. PNAS. 110(42), 16742-16747. https://doi.org/10.1073/pnas.1307520110.

Li, F., and Tang, G. (2011). DEM-based Terrain Factor of Soil Erosion at Regional Scale and Soil Erosion Mapping. In Ruas, A. Advances in Cartography and GIScience (Volume 2). Springer-Verlag Berlin Heidelberg. https://doi.org/10.1007/978-3-642-19214-2.

Maniwavie, T., Rewald, J., Aitsi, J., Wagner, T.P., and Munday, P.L, (2001). Recovery of corals after volcanic eruptions in Papua New Guinea. Coral Reefs. 20:24. https://doi.org/10.1007\%2Fs003380100114.

Marfai M.A., Ahmada B., Mutaqin B.W., Windayati R. (2020). Dive Resort Mapping and Network Analysis: Water Resources Management in Pemuteran Coastal Area, Bali Island, Indonesia. Geographia Technica. 15(2), 106-116. http://doi.org/10.21163/GT_2020.152.11.

Mutaqin, B.W. (2017). Shoreline Changes Analysis in Kuwaru Coastal Area, Yogyakarta, Indonesia: An Application of the Digital Shoreline Analysis System (DSAS). International Journal of Sustainable Development and Planning 12(7):1203-1214. https://doi.org/10.2495/SDP-V12-N7-1203-1214.

Mutaqin B.W. and Lavigne F. (2019), Oldest Description of a Caldera-forming Eruption in Southeast Asia Unveiled in Forgotten Written Sources, GeoJournal. https://doi.org/10.1007/s10708-019-10083-5.

Mutaqin B.W., Lavigne F., Sudrajat Y., Handayani L., Lahitte P., Virmoux C., Hiden, Hadmoko D.S., Komorowski J.C., Hananto N., Wassmer P., Hartono, Boillot-Airaksinen K. (2019a), Landscape evolution on the eastern part of Lombok (Indonesia) related to the $1257 \mathrm{CE}$ eruption of the Samalas Volcano, Geomorphology 327, 338-350. https://doi.org/10.1016/j.geomorph.2018.11.010.

Mutaqin B.W., Lavigne F., Hadmoko D.S., Malawani M.N. (2019b), Volcanic Eruption-Induced Tsunami in Indonesia: A Review, IOP Conf. Ser.: Earth Environ. Sci. 256 012023. https://doi.org/10.1088/17551315/256/1/012023.

Mutaqin B.W., Marfai M.A., Helmi M., Rindarjono M.G., Windayati R., Sunarto (2020), Spatio-temporal Mapping of Ecotourism Activities in Buleleng Conservation Zone: A Methodological Review, IOP Conf. Ser.: Earth Environ. Sci. 451 012095. https://doi.org/10.1088/1755-1315/451/1/012095.

Nistor, M-M., Rahardjo, H., Satyanaga, A., Leong, E-C., Hao, K.Z., Sham, A.W.L., Wu, H. (2019). GIS-Based Approach to Identify the Suitable Locations for Soil Sampling in Singapore. Geographia Technica, 14(1), 103-117. http://doi.org/10.21163/GT_2019.141.08.

Pradjoko, E., Bachtiar, I., Matalatta, N., Sugihartono, G. (2015). The Submerged Breakwater as Prototype of Coastal Protection in Gili Trawangan, Lombok, Indonesia. Procedia Engineering. 125, $284-290$. https://doi.org/10.1016/j.proeng.2015.11.041.

Ramalho, R., Quartau, R., Trenhaile, A., Mitchell, N., Woodroffe, C., \& Ávila, S. (2013). Coastal evolution on volcanic oceanic islands: A complex interplay between volcanism, erosion, sedimentation, sea-level 
change and biogenic production. Earth-Science Reviews. (127), 140-170. https://doi.org/10.1016/j.earscirev.2013.10.007.

Reguero, B.G., Beck, M.W., Agostini, V.N., Kramer, P. (2018). Coral reefs for coastal protection: A new methodological approach and engineering case study in Grenada. Journal of Environmental Management. 210, 146-161. https://doi.org/10.1016/j.jenvman.2018.01.024.

Reuter, M., and Piller, W.E. (2011). Volcaniclastic events in coral reef and seagrass environments: evidence for disturbance and recovery (Middle Miocene, Styrian Basin, Austria). Coral Reefs. 30, 889-899. https://doi.org/10.1007/s00338-011-0798-3.

Schils, T. (2012). Episodic Eruptions of Volcanic Ash Trigger a Reversible Cascade of Nuisance Species $\begin{array}{llllll}\text { Outbreaks in Pristine Coral Habitats. PLoS ONE } & \text { 7(10): }\end{array}$ https://doi.org/10.1371/journal.pone.0046639.

Schwendel, A., Fuller, I., \& Death, R. (2012). Assessing DEM interpolation methods for effective representation of upland stream morphology for rapid appraisal of bed stability. River Research and Applications, 28(5), 567-584. https://doi.org/10.1002/rra.1475.

Shepard, F.P. (1973). Submarine Geology (3rd edition). Harper and Row, New York. 517p.

Silva, R., Mendoza, E., Mariño-Tapia, I., Martinez, M.L., and Escalante, E. (2016). An artificial reef improves coastal protection and provides a base for coral recovery. Journal of Coastal Research. SI (75), 467-471. https://doi.org/10.2112/SI75-094.1.

Statistics Indonesia. (2017). Ekspor Menurut Kelompok Komoditi dan Negara. Buletin Statistik Perdagangan Luar Negeri. Jakarta: CV Josevindo.

Sutarna, I.N. (1990). Shape and condition of living coral colonies in the waters around Banda Islands, Central Maluku. In: Praseno D. P., Atmadja, W. S. (eds) Waters of the Maluku and its Environments. Indonesian Institute of Sciences (LIPI), Ambon. 135-147.

Tomascik, T., van Woesik, R., and Mah, A.J. (1996) Rapid coral colonization of a recent lava flow following a volcanic eruption, Banda Islands, Indonesia. Coral Reefs. 1, 169-175. https://doi.org/10.1007/BF01145887.

UNEP-WCMC, WorldFish Centre, WRI, TNC. (2018). Global distribution of coral reefs, compiled from multiple sources including the Millennium Coral Reef Mapping Project. Version 4.0, updated by UNEP-WCMC. Includes contributions from IMaRSUSF and IRD (2005), IMaRS-USF (2005), and Spalding et al. (2001). Cambridge (UK): UNEP World Conservation Monitoring Centre. URL: http://data.unepwcmc.org/datasets/1.

Vidal, C.M., Komorowski, J.-C., Métrich, N., Pratomo, I., Kartadinata, N., Prambada, O., Michel, A., Carazzo, G., Lavigne, F., Rodysill, J., Fontijn, K., Surono. (2015). Dynamics of the major Plinian eruption of Samalas in 1257 A.D. (Lombok, Indonesia). Bulletin of Volcanology. 77(9), 73. https://doi.org/10.1007/s00445-015-0960-9.

Vogel, S., \& Märker, M. (2010). Reconstructing the Roman topography and environmental features of the Sarno River Plain (Italy) before the AD 79 eruption of Somma-Vesuvius. Geomorphology (115), 67-77. https://doi.org/10.1016/j.geomorph.2009.09.031.

Vroom, P.S., and Zgliczynski, B.J. (2011). Effects of volcanic ash deposits on four functional groups of a coral reef. Coral Reefs. 30, 1025-1032. https://doi.org/10.1007/s00338-011-0793-8.

Zhu, X. (2016). GIS for Environmental Applications: A practical approach. Routledge, London, 490p. https://doi.org/10.4324/9780203383124.

Zimmerman, D., Pavlik, C., Ruggles, A., \& Armstrong, M. (1999). An Experimental Comparison of Ordinary and Universal Kriging and Inverse Distance Weighting. Mathematical Geology, 31(4), 375-390. https://doi.org/10.1023/A:1007586507433. 